\title{
PEMILIHAN KEPALA DAERAH SECARA LANGSUNG MERUPAKAN SARANA PELAKSANAAN DEMOKRASI DI INDONESIA
}

\author{
M. Agus Santoso \\ Dosen Fakultas Hukum Universitas Widya Gama Mahakam Samarinda
}

\begin{abstract}
ABSTRAK
Demokrasi merupakan suatu paham yang mengaku bahwa diantara semua orang untuk menentukan nasib kehidupannya sendiri oleh rakyat, dengan demikian rakyatlah yang menjalankan pemerintahan dalam suatu negara yang demokrasi. Di Indonesia yang menjalankan pemerintahan adalah ekskutif dalam hal ini Presiden, Gubernur, Bupati dan Walikota; sedangkan rakyat diberi hak untuk menentukan pilihannya secara suka rela pemimpin yang dikehendakinya untuk menjalankan pemerintahan, melalui Pilpres, untuk memilih Presiden dan Pilkada langsung untuk memilih kepala daerahnya. Pemilihan kepala daerah dan wakil kepala daerah diatur dalam Undang-Undang NO. 32 Tahun 2004, tentang Pemerintahan Daerah, tentu saja hal ini merupakan langkah menuju yang lebih demokrasi, karena dengan demikian kepala daerah dan wakil kepala daerah yang dipilih dapat menjalankan pembangunan di daerah secara leluasa karena telah mendapatkan kepercayaan dari rakyat melalui pemilihan kepala daerah secara langsung. Yang selama ini rakyat tidak pernah diberi kepercayaan untuk memilih kepala daerah pada periode sebelumnya, maka dari itu kehidupan demokrasi di Indonesia dapat dikatan lebih baik lagi karena rakyat sudah diberi peranan dan secara demokrasi pula. Namun demikian kepercayaan yang diberikan kepada rakyat oleh negara tersebut jangan sampai mengancam keutuhan Negara Kesatuan Republik Indonesia. Maka dari itu yang perlu diingat bahwa Pemilihan kepala daerah dan wakil kepala daerah secara langsung merupakan sarana menuju kehidupan demokrasi, tetapi demokrasi di Indonesia bukan demokrasi liberal, yaitu demokrasim Pancasila, yang tetap mempertahakan keutuhan Negara kesatuan Republik Indonesia.
\end{abstract}

Kata kunci : Pilkada langsung dan demokrasi.

\section{PENDAHULUAN}

Indonesia adalah negara yang mempunyai tujuan seperti termuat dalam alinea keempat Pembukaan Undang-Undang Dasar 1945, yaitu : 1. Melindungi segenap bangsa Indonesia, dan seluruh tumpah darah Indonesia, 2. Memajukan kesejahteraan Umum, 3. Mencerdaskan Kehidupan bangsa, dan 4. Ikut melaksanakan ketertiban dunia yang berdasarkan kemerdekaan, perdamaian abadi, dan keadilan sosial. Di samping itu Indonesia adalah negara yang menjunjung tinggi demokrasi, penegasan itu termua secara tegas di dalam Pasal 1 ayat (2) Undang-Undang dasar 1945 yang berbunyi :" Kedaulatan berada di tangan rakyat dan dilaksanakan menurut UndangUndang Dasar. Dengan demikian di Indonesia kekuasaan tertinggi ada di tangan 
yakyat namun demikian dalam implementasinya tentu rakyat tidak dapat menjalankannya sendiri secara baik, maka dari perlu adanya pemilmpahan kedaulatan dalam menjalankan tugas kenegaraan, terutama dalam menjalankan pemetrintahan negara.

Kekuasaan ekskutif (le pauvair executif), yang melaksanakan Undang-Undang, memaklumkan perang, mengadakan perdamaian dengan negara-negara lain, menjaga tata tertib, menindak pemberotakan dan lain-lain, dilaksanakan oleh pemerintah (Presiden atau Raja dengan bentuk kabinet). (Muchsin, 2004, hal : 2), Di Indonesia kekuasaan pemerintahan dipegang oleh Prsiden, termuat dalam Pasal 4 ayat (1) Undang-Undang dasar 1945, yang berbunyi :"Presiden Republik Indonesia memegang kekuasaan pemerintahan menurut Undang-Undang Dasar.". Kemudian dalam menjalankan pemerintahan, oleh karena luasnya wilayah Republik Indonesia, maka dibagi atas daerah-daerah provinsi dan daerah provinsi itu dibagi atas kabupaten dan kota, yang disebut daerah otonomi dipimpin oleh kepala daerah, seperti termuat dalam Pasal 18 ayat (4) Undang-Undang Dasar 1945 yang berbunyi :" Gubernur, Bupati, dan Walikota masing-masing sebagai kepala pemerintah daerah provinsi, kabupaten, dan kota dipilih secara demokrasi."

Dalam pengalaman sejarah kepemimpinan nasional maupun daerah di Indonesia menunjuklkan adanya pembatasan ruang gerak demokrasi yang dimiliki oleh rakyat, hal itu tercermin dari kepemimpinan nasional maupun daerah sejak Indonesia merdeka sampai era reformasi tidak pernah dipilih oleh rakyat secara langsung, maka sebaik apapun sebuah negara yang ditata secara demokrasi, tidak akan dianggap benar-benar demkratis mana kala pemimpin-pemimpinnya tidak dipilih secara bebas oleh rakyatnya sendiri, kemudian hal itu dijadikan tolak ukur untuk menentukan sebuah negara itu demokrasi atau tidak, walaupun demokrasi itu tidak semata-mata ditentukan adanya pemilihan kepala daerah secara langsung oleh rakyat. Hal itu tentu saja berkaitan dengan keberadaan Undang-Undang Dasar 1945 yang belum menentukan secara tegas tentang pemilihan kepala daerah secara langsung.

Setelah Undang-Undang Dasar 1945 mengalami perubahan sampai yang keempat kalinya barulah termuat bahwa kepala daerah dan wakil kepala daerah dipilih secara demokrasi, yang termuat dalam Pasal 18 ayat (4) Undang-Undang Dasar 1945, dan menurut Philipus M Hadjon yang dimuat dalam Titik Triwulan Tutik (2006) mengatakan bahwa : Prinsip demokrasi yang terkandung dalam Pasal 18 (ayat 3 dan 4 ) menyangkut pemilihan anggota DPRD dan Kepala Daerah secara langsung, dengan demikian dalam sistem ketatanegaraan Republik Indonesia, pemilihan umum tidak hanya untuk memilih wakil rakyat (DPR, DPD, DPRD), tetapi juga untuk kepala pemerintahan. (Philipus M Hadjon, dalam Titik Triwulan Tutik, 2006, hal : 218).

Pemilihan kepala daerah dan wakil kepala daerah secara langsung pada dasarnya merupakan suatu proses politik bangsa menuju kehidupan yang lebih demokrasi (kedaulatan rakyat), serta transparan dan bertanggungjawab, selain itu pemilihan kepala daerah dan wakil kepala daerah secara langsung tersebut menandakan adanya perubahan dalam demokrasi lokal, yakni tidak sekedar distribusi kekuasaan antar tingkat pemerintah secara vertikal, tetapi juga merupakan sarana pelaksanaan kedaulatan rakyat di wilayah provinsi maupun kabupaten dan kota berdasarkan Pancasila dan Undang-Undang Dasar 1945. 
Sinyalemen pemilihan kepala daerah dan wakil kepala daerah secara langsung jika ditinjau dari sudut pandang ketatanegaraan dan pemerintah akan membuahkan suatu kondisi pertama : pemilihan kepala daerah akan menghasilkan pemerintahan daerah yang mempunyai legitimasi langsung dari masyarakat dimana pemerintah daerah mempunyai pertanggung jawaban politik dan akuntabilitas yang tidak akan semana-mena menyeleweng, kedua : iklim menumbuhkan kondisi daerah menemui moment, dalam arti bahwa peran kepala daerah yang didukung peraturan mampu membawa katalisator konstruktif bagi kemajuan masyarakat; ketiga : pemilihan kepala daerah, secara esensial akan mendukung demokrasi lokal, yaitu masa depan kehidupan masyarakat di daerah menjadi cerah akibat terbukanya ruang publik melalui partisipasi proaktif masyarakat. (ibid hal : 221).

Untuk melaksanakan maksud dan tujuan pemilihan kepala daerah dan wakil kepala daerah secara langsung sebagai sarana kedaulatan rakyat di suatu daerah yang telah di atur secara konstitusional di dalam Undang-Undang Dasar 1945, secara tegas pula diatur dalam Pasal 56 ayat (1) Undang-Undang Nomor 32 Tahun 2004, tentang Pemerintahan Daerah, yang menyatakan :"Kepala daerah dan wakil kepala daerah dipilh dalam satu pasangan calon yang dilaksanakan secara demokratis berdasarkan asas langsung, umum, bebas, rahasia, jujur dan adil." Hal ini tentu sama dengan asas yang di pakai dalam pemilihan umum untuk memilih DPR, DPD dan DPRD, maka dengan demikian pemilihan kepala daerah juga merupakan sarana dalam rangka menjalankan demokrasi yang dimilki oleh rakyat, dalam rangka menjalankan kedaulatannya.

Penggunaan asas langsung, umum, bebas, rahasia, jujur dan adil tersebut merupakan konskwensi sebagai pelaksanaan pemilihan secara demokrasi. Hal ini juga sependapat dengan Mahkamah Konstitusi Republik Indonesia :"Dalam menjabarkan maksud "dipilih secara demokrasi" dalam pasal 18 ayat (4) Undang-Undang Dasar 1945, pembuat Undang-Undang telah memilih cara pemilihan Kepala daerah secara langsung, maka sebagai konskwensi logisnya, asas-asas penyelenggaraan pemilihan umum harus tercermin dalam penyelenggaraan pemilihan kepala daerah secara langsung, yaitu langsung, umum, bebas, rahasia, jujus, dan adil (luber). (Putusan Mahkamah Konstitusi RI, Nomor : 027-073/PPU-II/2004).

Pemilihan kepala daerah dan wakil kepala daerah secara langsung sebagai instrument demokrasi dalam rangka menjaring kepemimpinan nasional tingkat daerah, walaupun tidak dilaksanakan secara serentak di seluruh Indonesia seperti pemilihan umum legislatif pada umumnya, tetapi hal ini merupakan sebuah kemajuan politik demokrasi di Indonesia khususnya dalam hal memilih pemimpinnya di daerah secara langsung oleh trakyat, yang selama kurun waktu lebih 50 tahun belum pernah terjadi di Indonesia, bahkan selama itu pula selama itu pula keberadaan kepala daerah tidak lebih dari boneka pemerntah pusat untuk menjalankan kepentingannya di daerah dengan alasan kepentingan nasional, tetapi di satu sisi demkokrasi dibelenggu dan tidak dijalankan secara optimal. Namun setelah terjadinya reformasi, seperti membalikkan telapak tangan, situasi politik demokrasi berubah seratus delapan puluh derajat, dari mulai perubahan Undang-Undang politik, Undang-Undang Pemilihan Umum, Undang-Undang Dasar 1945 juga Undang-Undang Pemerintah Daerah termasuk di dalamnya mengatur tentang pemilihan kepala daerah secara langsung. 
Tentunya hal ini merupakan kajian yang manarik untuk diteliti dan di bahas dalam kajian hukum tata negara, agar didapat jawaban atas permasalah yang dihadapinya maka penulis tertarik untuk mengadakan penelitian yang berkaitan dengan pemilihan kepala daerah secara langsung yang berkaitan dengan pelaksanaan kedaulatan rakyat di Indonesai yang diatur dalam, Undang-Undang Dasar 1945, atas dasar hal tersebut penulis menuangkannnya dalam sebuah tulisan ini dengan judul : Pemilihan Kepala daerah Secara Langsung Sebagai Sarana Pelaksanaan Demokrasi Di Indonesia."

\section{RUMUSAN MASALAH}

Dalam peneletian ini yang menjadi masalah adalah :

1. Mengapa Pemilihan Kepala Daerah Secara Langsung Dilaksanakan di Indonesia ?

2. Faktor-faktor Apa Saja Sebagai Pendukung dan Penghambat Pemilihan Kepala Daerah Secara Langsung di Indonesia?

\section{TUJUAN PENELITIAN}

Adapaun yang menjadi tujuan dalam penelitian ini adalah hal-hal yang sesuai dengan permaslahan yang ada, yaitu :

1. Untuk mengetahui mengapa pemilihan kepala daerah secara langsung dilaksanakan di In donesia.

2. Untuk mengetahui faktor-faktor pendukung dan penghambat pemilihan kepala daerah langsung di Indonesia.

\section{METODE PENELITIAN}

Dalam penelitian ini hal utama yang dibahas adalah mengenai pemilihan kepala daerah secara langsung di Indonesia, yang merupakan kajian hukum tata negara, maka penelitiannya adalah penelitian hukum, yaitu sebagai penelitian untuk menemukan hukum in concreto yang meliputi berbagai kegiatan untuk menemukan apakah yang merupakan hukum yang layak untuk ditetapkan secara in concreto untuk menyelesaikan suatu yang didasarkan pada metode, sistematika dan pemikiran tertentu, dengan jalan menganalisisnya. (Soerjono Soekanto, 2005, hal : 43 \}.

Adapaun jenis penelitiannya adalah penelitian hukum normatif, yang menggunakan metode doktrinal monolagi, yaitu bertolak dari kaidah sebagai ajaran yang mengkaidahi perilaku, (Bernard Arief Sidharta, 1996, hal 190), kemudian penelitian hukum normatif ini mengkaji hukum yang dikonsepkan sebagai norma atau kaidah yang berlaku dalam masyarakat dan menjadi acuan perilaku setiap orang, sedangkan norma hukum yang berlaku itu berupa norma hukum positif tertulis bentukan lembaga perundang-undangan (Undang-Undang Dasar), kodifikasi, Undang- 
Undang, Peraturan Pemerintah dan hukum tertulis bentukan lembaga peradilan (judge made law), serta norma hukum tertulis buatan pihak-pihak yang berkepentingan (kontrak, dokuman hukum, laporan hukum, cacatan hukum, dan Rancangan UndangUndang), oleh karena itu, penulisan hukum normatif ini disebut juga penelitian hukum teoritis/dogmatik, karena tidak mengkaji pelaksanaan atau implementasi hukum, fokus kajiannya adalah inventarisasi hukum positif, asas-asas dan doktrin hukum, penemuan hukum dalam perkara in concreto, sistematik hukum, taraf sinkronisasi hukum, perbadingan hukum, dan sejarah hukum.(ibid).

Bahan hukum yang diperlukan dalam penelitian ini adalah bahan hukum primer berupa Undang-Undang Dasar 1945 maupun Undang-Undang yang berkaitan dengan pemilihan kepala daerah secara langsung, karena menurut Sunaryati Hartono (1994) Bagi penelitian hukum normatif, bahan-bahan primer terdiri atas Undang-Undang Dasar dan berbagai dokumen resmi yang memuat ketentuan hukum, termasuk akta notaris dan kontrak, sedangkan texbook, monograf, laporan penelitian dan sebagainya, merupakan bahan sekunder,(C.F.G. Sunaryati Hartono, 1994, hal : 151).

\section{KERANGKA TEORI}

Kerangka teori diperlukan untuk menganalisis beberapa masalah yang dihadapi, sedangkan dalam penelitian ini masalahnya bertitik tolak pada pemilihan kepala daerah secara langsung oleh rakyat, merupakan pengejawantahan dari sistem kedaulatan rakyat, kemudian digunakanlah konsep demokrasi sebagai teori utama (grend teory), dan menurut asal katanya demokrasi berasal dari kata demos yang berarti rakyat, dan cratein yang berarti mengatur pemerintahan. (Usep Ranawijaya, 1983, hal : 91), Maka berdasarkan pengertian tersebut secara etimologi demokrasi berarti pemerintahan dari, oleh, dan untuk rakyat, berarti pemerintahan oleh rakyat yang dengan demikian mendasarkan hal ihwal kenegaraannya pada kekuasaan rakyat, sehingga rakyatlah yang berdaulat.(Padmo Wahjono, 1986, hal : 75).

Menurut kamus hukum, demokrasi (democratie) adalah bentuk pemerintahan atau kekuasaan negara yang tertinggi, dimana sumber kekuasaan negara yang tertinggi adalah kekuasaan (ke) rakyat (an) yang terhimpun melalui suatu majelis dinamakan Mejelis Permusyawaratan Rakyat (de gesamte staagewaltliegt allein bei der majelis), (Yan Pramudya Puspa, 1977, hal : 295). Selain itu, kamus Dictionary Webters mendefinisaikan, demokrasi adalah pemerintah oleh rakyat di mana kekuasaan tertinggi berada di tangan rakyat dan dijalankan langsung oleh mereka atau oleh wakilwakil yang mereka pilih di bawah sistem pemilihan bebas. (Sabirin Malian, 2001, hal : 44). Berdasarkan pengertian tersebut, maka konsep demokrasi berakar dari konsep kedaulatan rakyat, dan menurut ajaran kedaulatan rakyat, kekuasaan tertinggi ada pada rakyat, artinya bahwa pada tingkat terakhir rakyatlah yang memberi keputusan dalam mesalah pokok mengenai kehidupannya, termasuk dalam menilai kebijaksanaan pemerintah dan negara. Dalam perspektif demikian, negara ada karena kemauan bersama dari rakyatnya, selama negara itu ada, maka segala tindakan harus sesuai dengan kemauan rakyatnya, oleh karena itu, organisasi dan perjalanan negara seharusnya ditetapkan oleh kemauan bersama. (M. Nasroen, 1986, hal : 66). 
Perkataan "dari rakyat" maksudnya bahwa penyelenggaraan negara harus terdiri dari seluruh rakyat itu sendiri atau yang disetujui atau didukung oleh rakyat. Olah rakyat maksudnya adalah bahwa penyelenggaraan negara dilakukan sendiri oleh rakyat atau atas nama rakyat atau yang mewakili rakyat, maksudnya pemerintahan dijalankan atau berjalan sesuai dengan kehendak rakyat. Berdasarkan ganbaran tersebut, tampak jelas bahwa dalam negara demokrasi, rakyat merupakan sumber kekuasaan, artinya dalam proses bernegara, rakyat sering dianggap sebagai hulu dan sekaligus muaranya, rakyat merupakan titik sentral dan pemegang kedaulatan atau benar-benar berdaulat. (I Gde Pantja Astawa, 2000, hal : 30). Namun demikian dalam praktek tentu tidak mungkin sekian banyak rakyat dalam suatu negara menjalankan kedaulatan jalannya pemerintahan negara, oleh karena itu yang dimaksudkan adalah, dalam hal menentukan siapa yang menjalankan pemerintahan negara atau daerah itu ditentukan oleh rakyat secara demokrasi, dan dalam suatu daerah pemimpin yang menjalankan pemerintah daerah juga ditentukan oleh rakyatnya melalui pemilihan kepala daerah secara langsung, umum. Bebas, rahasia, jujur dan adil. Inilah yang dimaksud bahwa kedaulatan berada di tangan rakyat, dalam konsep demokrasi.

Konsep demokrasi di Indonesia tercermin dalam Bab I Undang-Undang Dasar 1945 tentang Bentuk dan Kedaulatan, kemudian pada Pasal 1 ayat (2) Undang-Undang Dasar 1934 menyatakan :"Kedaulatan berada di tangan rakyat dan di jalankan menurut Undang-Undang Dasar". Hal ini mengandung arti bahwa di dalam Undang-Undang Dasar 1945 disamping mengatur tentang kedaulatan rakyat juga mengatur tentang bagaimana bentuk kedaulatan yang dilakukan oleh rakyat. Jika dikaitkan dengan Bab III Undang-Undang Dasar 1945, tetang Kekuasaan Pemerintahan Negara, Pasal 4 ayat (1) Undang-Undang Dasar 1945, menyatakan bahwa Presiden Republik Indonesia memegang kekuasaan pemerintahan menurut Undang-Undang Dasar. Berarti kedaulatan negara berada pada Presiden, tetapi pada Pasal 6A ayat (1) Undang-Undang Dasar 1945, menyatakan bahwa :'Presiden dan Wakil Presiden dipilih dalam suatu pasangan secara langsung oleh rakyat."

Kaliman dipilih dalam suatu pasangan secara langsung oleh rakyat mengandung arti bahwa rakyat mempunyai kewenangan sepenuhnya untuk menentukan Presiden sebagai kepala pemerintahan, dengan demikian Presiden dalam menjalankan tugasnya mendapat mandat dari rakyat melalui pemilihan Presiden tadi, maka Presiden harus melaksanakan tugasnya sesuai dengan kehendak rakyat yang memberikan mandat untuk menjalankan pemerintahan Negara Republik Indonesia. Kemudian oleh karena luasnya wilayah, Negara Kesatuan Republik Indonesia dibagi atas daerah-daerah provinsi dan daerah provinsi itu dibagi atas kabupaten dan kota, yang tiap-tiap provinsi, kabupeten, dan kota itu mempunyai pemerintahan daerah, yang diatur dengan Undang-Undang, demikian bunyi Pasal 18 ayat (1) Undang-Undang Dasar 1945. Kemudian Pasal 18 ayat (4) Undang-Undang Dasar 1945 menyatakan bahwa Gubernur, Bupati, dan Walikota masing-masing sebagai kepala pemerintah daerah provinsi, kabupaten, dan kota dipilih secara demokratis. Kemudian desebut dengan pemilihan kepala daerah secara langsung.

Pasal 24 Undang-Undang Nomor 32 Tahun 2004, tentang Pemerintah Daerah menyatakan bahwa :"Setiap daerah dipimpin oleh kepala pemerintah daerah yang disebut kepala daerah." Mengenai pemilihan kepala daerah secara langsung diatur dalam Pasal 56 Undang-Undang Nomor 32 Tahun 2004, tentang Pemerintahan Daerah yang berbunyi :'Kepala daerah dan wakil kepala daerah dipilih dalam satu pasangan 
calon yang dilaksanakan secara demokratis, berdasarkan asas langsung, umum, bebas, rahasia, jujur, dan adil." Kemudian Pasal 24 ayat (5) Undang-Undang Nomor 32 Tahun 2004, tentang Pemerintahan Daerah menyebutkan :'Kepala daerah dan wakil kepala daerah sebagaimana pada ayat (2) dan ayat (3), dipilih dalam satu pasangan secara langsung oleh rakyat di daerah yang bersangkutan." Demngan demikian jelaslah bahwa pernyataan pasal-pasal ini rakyat mempunyai kewenangan untuk menentukan siapa yang pantas untuk menjalankan pemerintahan yang notabene adalah hak mutlak rakyat yang memegang kedaulatan, dan rakyat memberikan kakuasaan itu kepada kepala daerah yang sudah dipilihnya secara demokrasi pula.

\section{PEMBAHASAN}

\section{A. Alasan Dilaksanakannya Pemilihan Kepala Daerah Secara Langsung}

\section{Di Indonesia.}

Pemilihan kepala daerah dan wakil kepala daearh secara langsung, telah diatur dalam Undang-Undang Nomor 32 Tahun 2004, tentang Pemerintahan Daerah, mulai dari Pasal 56 sampai dengan Pasal 118, sehingga kepala dan wakil kepala daerah bukan hanya berperan sebagai wakil dari pemerintah pusat. Kepala daerah dan wakil kepala daerah yang telah dipilih secara demokrasi, benar-benar bisa melaksanakan pembangunan yang sesuai dengan kehendar rakyat di daerah, namun demikian tetap harus menjaga keutuhan Negara Kesatuan Republik Indonesia. Jangan sampai ada cara pandang yang salah dalam memahami otonomi daerah secara luas, sehingga terlalu berlebihan, bahkan memahami otonomi daerah sebagai kebebasan yang bersifat mutlak, dan pada akhirnya mengancam nilai-nilai luhur yang terkandung Pembukaan Undang-Undang Dasar 1945.

Perjalanan sejarah kepemimpinan nasional yang ada di daerah selama itu belum pernah terjadi, sejak Indonesia merdeka sampai masa reformasi, rakyat belum pernah diberi kewenangan untuk menentukan pilihannya terhadap pemimpinnya di daerah, hal ini menimbulkan pertanyaan besar bagi daerah sehiongga muncul gagasan untuk dilaksanakan pemilihan kepala daerah secara langsung. Di awali dengan perubahan Undang-Undang dasar 1945 Pasal 18 ayat (4) yang menyatakan :"Gubernur, Bupati, dan Wali kota masing-masing sebagai kepala pemerintah daerah provinsi, kabupaten, dan kota dipilh secara demokrasi." Kemudian Pasal 56 ayat (1) Undang-Undang Nomor 32 Tahun 2004, tentang \{emerintahan Daerah menyebutkan bahwa :"Kepala daerah dan wakil kepala daerah dipilih dalam satu pasangan calon yang dilaksanakan secara demokratis berdasarkan asas langsung, umum, bebas, rahasia, jujur, dan adil."

Adapun beberapa alasan mengapa pemilihan kepala daearah secara langsung merupakan suatu solusi untuk mencapai keseimbangan dalam distribusi kekuasaan pemerintah daerah, yakni alasan secara yuridis sebenarnya Undang-Undang Dasar 1945 sudah mempunyai keinginan yang kuat untuk melaksanakan pemilihan kepala daerah secara langsung dalam rangka melaksanakan kedaulatan rakyat, dimana lembaga kekuasaan yang lain seperti legislatif (DPR, DPD dan DPRD), juga termasuk ekskutif (Presiden dan Wakil Presiden) telah dipilih secara langsung oleh rakyat, maka seharusnya pulalah kepala daearh yang sederajad dengan DPRD juga dipilih secara langsung oleh rakyat. Dan ketika pemilihan secara langsung itu tidak terlaksana 
terhadap pemilihan kepala daerah, tentu menimbulkan pertentangan prinsip dalam Undang-Undang Dasar 1945, karena adanya asas tertentu yang tidak digunakan, yakni asas keadilan yang merata.

Menurut asas keadilan yang merata, bahwa hukum nasional bertujuan untuk terus meningkatkan keadilan dan kesejahteraan masyarakat secara merata. (Padmo Wahjono, 1985, hal : 6). Ketidak adilan dalam materi tersebut, dapat menyentuh pada rakyat dan juga bagi kepala daearh. Ketidak adilan bagi rakyat, karena rakyat tidak dapat menentukan pilihannya langsung sesuai hati nurani pada calon pemimpinnya. Sebaliknya ketidak adilan bagi kepala daerah, karena semua anggota (yang menduduki) lembaga kekuasaan politis yang berwenang dalam pengambilan putusan politis atau lembaga yang bersentuhan langsung dengan konsep kedaulatan rakyat (DPR, DPD, dan DPRD) sebagai lembaga legislatif maupun Presiden dan Wakil Presiden sebagai lembaga ekskutif, telah dipilih secara langsung oleh rakyat melalui pemilihan umum, sedangkan kepala daerah juga berposisi sama dengan lembagalembaga tersebut, yakni sebagai lembaga ekskutif darah.

Sedangkan alasan politisnya, adalah untuk mendapatkan legitimasi kekuasaan berdasarkan dukungan mayoritas rakyat setempat, sebagai bentuk upaya untuk melaksanakan demokrasi dan demokratisasi didaerah (Syaukani, HR. 2004. Hal :185). Dukungan yang kuat dari rakyat setempat menjadi urgen dalam menjalankan pemerintahan, karena menurut konsep kedaulatan rakyat, dalam hal ini rakyatlah yang mengambil keputusan tertinggi dan rakyat juga yang paling berwenang menentukan siapa yang jadi wakilnya untuk menyelenggarakan pemerintahan, karena intinya rakyatlah yang memegang lingkup kedaulatan/kekuasaan (Scope Of Sovereignity/Scope Of Power) dan dominan kedaulatan/kekuasaan (domain of sovereignity/domain of power).(Jimli Asshiddiqie, 1994, hal: 9. Dimuat juga dalam Sayuti Una, 2004, hal 213).

Adapun alasan secara empiris mengapa kepala daerah harus dipilih secara langsung, tentunya tidak lain kecuali melihat implementasi selama ini yang cenderung meninggalkan prinsip-prinsip hukum dan keadilan. Pada masa orde baru maupun orde lama proses pemilihan kepala daerah menjadi wewenang pihak pemerintah (ekskutif) pusat sepenuhnya, Maka konskwensinya posisi kepala daerah tak ubahnya seperti robot yang dikendalikan kemana saja sesuai dengan kemampuan pihak pemerintah pusat. Kepentingan pusat belum tentu sama dengan kepentingan masyarakat daerah, asas persamaan kedudukan dalam hukum (equality before the law) serta asas keadilan yang merata, karena praktek itu dapat menghilangkan kesempatatan bagi warga negara yang memenuhi syarat secara umum untuk menduduki jabatan publik. (Sunaryati Hartono, 1988, hal : 73. Dimuat dalam Sayuti Una, op cit, hal : 211).

Pemilihan kepala daerah dan wakil kepala daerah secara langsung pada dasarnya merupakan suatu proses politik bangsa menuju kehidupan yang lebih demokratis (kedaulatan rakyat), serta transparan dan bertanggung jawab, selain itu pemilihan kepala daerah dan wakil kepala daerah secara langsung tersebut, menandakan adanya perubahan dalam demokrasi lokal, yakni tidak sekedar distribusi kekuasaan antar tingkat pemerintah secara vertikal. Kenyataan itu dapat dipahami, sebagaimana disebutkan dalam Pasal 1 ayat (1) Peraturan Pemerintah tentang pemilihan kepala daerah dan wakil kepala daerah yang selanjutnya disebut pilkada, adalah sarana 
pelaksanaan kedaulatan rakyat diwilayah provinsi, kabupaten dan kota, berdasarkan Pancasila dan Undang-Undang Dasar 1945.

Pemilihan kepala daerah dan wakil kepala daerah secara langsung juga diharapkan kepala daerah dan wakil kepala daerah yang bersangkutan dapat mengenal wilayah dan keragaman agama, adat, budaya serta kelompok (suku) rakyatnya, sehingga dapat membangun kultur demokrasi yang sesuai dengan keragaman tersebut. Dengan kata lain pemilihan kepala daerah secara langsung dapat menciptakan seorang kepala daerah yang mengenal dan dikenal daerah serta rakyatnya. Akan sulit menciptakan seperti kondisi tersebut, jika kepala daerahnya masih dipilih oleh DPDR maupun pemerintah pusat, karena kemauan keduanya belum tentu sama dengan aspirasi rakyat. Dengan memiliki wewenang yang ada padanya, baik DPRD maupun pemerintah pusat, dapat memilih kepala daerah meskipun sebanarnya tidak mengenal dan tidak dikenal daerah serta rakyat setempat. Dalam kondisi ini, walaupun prasyarat mengenal dan dikelnal tersebut masih digunakan, maka intinya hanyalah berbentuk semu atau yang sengaja dibuat-buat.

\section{B. Faktor Pendukung Dan Penghambat Pemilihan Kepala Daerah}

\section{Secara Langsung.}

Pemilihan klepala daerah secara langsung sebagai instrument demokrasi dalam rangka menjaring kepemimpinan nasional tingkat daerah, oleh karena itu diperlukan seperangkat sarana dan prasaran sebagai pendukung peleksanaan pemilihan kepala daerah secara langsung, agar tercapai tujuan yang dikehendainya yaitu pelaksanaan pemilihan kepala daerah yang berasaskan langsung, umum, bebas, rahasia, jujur dan adil. Berkaitan dengan hal tersebut dalam penyelenggaraan suatu pemlihan kepala daerah provinsi maupun kabupaten dan kota diperlukan adanya suatu lembaga yang bersifat mandiri (independen), seperti yang diatur dalam Pasal 57 ayat (1) Un dangUndang Nomor 32 Tahun 2004, tentang Pemerintahan Daerah, yang menyatakan :'Pemilihan kepala daerah dan kepala daerah diselenggarakan oleh KPUD yang bertanggung jawab kepada DPRD."

Sebagai lembaga yang independen KPUD harus bebas dari intervensi lembaga negara manapun dalam penyelenggaraan pemilihan kepala daerah. Ketentuan tersebut cukup logis dengan memandang bahwa amat sulit mencapai tujuan tersebut apabila KPUD harus bertanggung jawab kepada lembaga lain semisal DPRD, karena DPRD merupakan unsur-unsur partai politik yang menjadi pelaku dalam kompetisi pemilihan kepala daerah secara langsung. Ketentuan jaminan independen KPUD dalam melaksanakan Pemilihan Kepala daerah secara langsung ini adalah keinginan melepaskan kepentingan KPUD kepada lembaga lain, atau dengan kata lain ingin memelihara lembaga yang aparatnya adalah KPU Provinsi/Kabupaten/Kota.(Taufiqurrahman Syahari, yang dimuat dalam Titik Triwulan Tutik, 2004, hal : 223)

Berbagai polemik muncul di permukaan berkaitan dengan pelaksanaan pemilihan kepala daerah secara langsung tersebut, antusiasme dan harapan masyarakat untuk dapat memilih secara langsung kepala daerahnnya sangat terasa di masyarakat. Inilah saat yang tepat untuk menentukan pilihan kita secara langsung, dan ikut bertanggung jawab dengan pilihannya; Dan sebelumnya telah tercatat keberhasilan masyarakat dalam pemilihan umum legislatif, yang kemudian disusul dengan pelaksanaan 
pemiliuhan Persiden dan Wakil Presiden secara langsung, yang membawa kesuksesan besar, inilah yang harus etrus diperjuangkan dan terus dijaga dan ditingkatkan kwalitasnya sampai memasuki arena pemilihan kepala daerah secara langsung pula.

Secara demokrasi memang pemilihan kepala daerah secara langsung baik dan kelihatan demokrasi secara konstitusional, tetapi secara ekonomis tentu mengeluarkan biaya yang begitu besar, olah karena itu harus dapat disederhanakan sedemikan rupa agar tidak telalu banyak mengeluarkan biaya, yang perlu diingat bahwa masih banyak rakyat miskin di daerah-daerah, benarkah pemilihan kepala daerah secara langsung akan berimbas kepada kesejahteraan rakyat di daerah. Kemudian yang harus diwaspadai pula adalah adanya politik uang, karena bentuk-bentuk pragmatisme masih banyak terjadi, dan masyarakat juga tidak sedikit yang berpikir demikian, sehingga akan menghasilkan pemimpin yang benar-benar bisa mengayomi masyarakat, tetapi malahan setelah menjadi kepala daerah akan mengeruk keuntungan yang lebih besar lagi, sehingga cenderung malakukan korupsi, inilah yang dikawatirkan mengenai pelaksanaan pemilihan kepala daerah secara langsung.

Faktor penghambat lainnya adalah, kurangnya memahami demokrasi yang sesungguhnya, terlihat dibeberapa tempat terjadi perbuatan anarkis bagi yang kalah, sehingga melakukan pengrusakan-pengrusakan sarana umum yang sudah barang tentu menimbulkan kerugian besar bagi daerah yang bersangkutan, padahal di dalam Undang-Undang sudah ada sarana untuk mengajukan keberatan bagi yang merasa dirugikan, tetapi dibeberapa tempat kejadian tersebut ada calon-calon dan pendukungnya yang siap menang tetapi tidak siap kalah, sehingga melakukan anarkisme dengan tuduhan bahwa KPUD telah melakukan kesalahan dan lain sebagainya, Terlepas benar atau tidaknya ada kesalahan yang dilakukan oleh KPUD, semua pihak harus belajar dewasa, bahwa untuk menegakkan demokrasi memang harus dibayar mahal, dan perjuangan yang melelahkan.

\section{KESIMPULAN}

1. Bahwa pemilihan kepala daerah secara lengsung harus dilaksanakan di Indonesia, karena selama lebih dari limapuluh tahun Indonesia merdeka kepala daerah selalu dipilih oleh pemerintah pusat. Disamping itu dalam rangka menjalankan asas keadilan yang merata, agar dapat menghasilkan pemilihan yang demokrasi dan menghasilkan pemimpin di daerah yang sesuai dengan kehendak rakyat yang dipimpinnya, secara politikpun terdapat legitimasi kekuasaan berdasarkan dukungan masyarakat.

2. Adapun faktor-faktor pendukungnya bahwa pemilihan kepala daerah secara langsung dilaksanakan oleh sebuah lembaga independen yang disebut KPUD, agar dapat menyelenggarakan pemilihan kepala daerah yang profesional. Sedangkan faktor penghambatnya adalah bahwa dimana-mana masih terjadi anarkisme, dengan tuduhan bahwa KPUD telah melakukan kesalahan dan sebagainya. Politik uang juga merupakan faktof penghambat perkembangan demokrasi di Indonesia.

\section{DAFTAR PUSTAKA}


Arif Sidharta, Bernart. Refleksi tentang fundasi dan Sifat Keilmuan Ilmu Hukum Sebagai Landasan Pengembangan Ilmu Hukum Nasional (disertasi) Pasca Sarjana UNPAD, Bandung, 1996.

Asshiddiqie, Jimly. Gagasan Kedaulatan Rakyat dalam Konstitusi dan Pelaksanaannya di Indonesia, PT. Ichtiar Baru Van Hoeve, Jakarta, 1994.

Astawa, I Gde Pantja, Hak Angket Dalam Sistem Ketatanegaraan Indonesia Menurut UUD 1945 (disertasi) Pascasarjana UNPAD Bandung, 2000.

Hadjon, Philipus M, Pengantar Hukum ASdministrasi Indonesi, Editor Gajah Mada Univ. Press, 1994.

Hartono, Sunaryati, Penelitian Hukum di Indonesia Pada Akhir Abad ke-20, Alumni, Bandung 1994.

Hartono Sunaryati, Asas-asas Hukum Dalam Pembentukan peraturan perundangundangan, Dalam Majalah BPHN No. 2, Departemen Kehakiman RI, Jakarta, 1988.

HR, Syaukani, Otonomi Daerah Dalam Negara kesatuan (PUSKAB), Penerbit Pustaka Pelajar, Yogyakarta, 2002.

Malian, Sabirin, Gagasan Perlunya Konstitusi Baru Pengganti UUD 1945, UII Press, Yogyakarta, 2001.

Muchsin, Kekuasaan Kehakiman yang Merdeka \& Kebijakan Asasi, STIH "IBLAM" Jakarta, 2004.

Nasroen, M. Asal Mula Negara, Aksara Baru, Jakarta, 1986.

Ranawijaya, Usep,Hukum Tata Negara Indonesia Dasar-dasarnya, Galia Indonesia, Jakarta, 1083.

Tutuik, Titik Triwulan, Pokok-pokok Hukum Tata Negara, Prestasi Pelajar, Jakarta 2006.

Una, Sayuti, Pereseran Kekuasaan Pemerintahan daerah menurut Konstitusi Indonesia, UII Press, Yogyakarta, 2004.

Wahjono, Padmo Indonesia Negara Berdasarkan atas Hukum, Ghalia Indonesia, Jakarta, 1986 